\title{
406 ディーゼルエンジンとガソリンエンジンにおける各種騒音成分の比較
}

Comparison of Various Noises in Diesel Engine and Gasoline Engine

学 $\bigcirc$ 田中宏巳 (山口大院) 正 三上真人 (山口大) 正 小嶋 直哉（山口大)

Hiromi TANAKA, Graduate School of Yamaguchi University, 2-16-1 Tokiwadai, Ube, Yamaguchi 755-8611

Masato MIKAMI, Yamaguchi University

Naoya KOJIMA, Yamaguchi University

Key Words : Diesel Engine, Gasoline Engine, Engine Noise, Combustion Noise, Time-Frequency Analysis,

\section{1. 緒言}

エンジン騒音は, エンジン構造内で様々な衝撃が発生しそ れが加振源となって振動が伝達し，エンジン外壁面で騒音が 放射される.エンジン騒音を衝撃源によって大別すると, 燃 狫衝撃による燃烵衝撃音, 燃焼衝撃によって誘起されて発生 するピストンスラップやベアリングなどの機械的な衝撃によ る燃焼誘起機械騒音とその他のバルブやギアなどの衝撃によ る機械騒音に分類される。これらの各種騒音は発生時期およ び発生機構が異なり,また機阅の構造によっても発生特性が 变化する.よって騒音の低減化においては, これらの騒音の 発生特性を把握することが重要である。本研究では点火方式 の異なるディーゼルエンジンとガソリンエンジンを用いて， 時間周波数解析を行い，各種騒音成分の比較検討を行った。

\section{2. 実験装置}

本実験では供試エンジンとして水冷 4 サイクル単気筒ディ 一ゼルエンジンと空冷 4 サイクル単気筒ガソリンエンジンを 使用した。この供試エンジンの主要諸元を表 1 に示す.

供試エンジンは防音無響室の定盤に設置して，エンジン騒 音以外の騒音の発生および音の反射を防止するために定盤の まわりをグラスウールで囲み，その上に鉛シートを被せた。 また吸排気系の音を除去するために，吸気を室外から導入し， 排気は室外に排出して排気管のまわりを鉛とグラスウールで 吸遮音した。

エンジンのシリンダ内圧力の測定には圧カピックアップを 用いた。シリンダ内圧力の正確な周波数特性が得られるよう ピックアップをシリンダヘッド内壁面にフラッシュマウント した. 5 個の精密騒音計を半径 $1 \mathrm{~m}$ の半球面上に設置し, 5 点の騒音のパワー平均值によりエンジン騒音のパワーを算出 した. 加速度ピックアップを用いて，エンジン外壁面に取り 付け, 振動を測定した. TDC の検出には光電式検出器を用 いた。測定した各応答波形は，DAT レコーダに記録しここ れらの信号を A/D 変換器によりデジタル信号に変換し， マ イクロコンピュータに取り込んだあと，解析を行った。負荷 の測定には，ディーゼルエンジンでは動力計用いた。ガりリ ンエンジンでは出力軸にプロニー動力計を取り付けバネばか りにより負荷を検出した。

解析では，nVision を用いてウェーブレット解析を行った。 マザー関数には，Morlet 関数を使用した。

\section{3. 燃焼衝撃音の算出}

本研究では，エンジン騒音の主成分と考えられる燃焼衝撃 音を算出するために単一爆発加振実験を行い, 騒音の発生モ デルを定義した。単一爆発加振実験とは, 静止したエンジン 内で燃焼衝撃のみを発生させ，燃焼衝撃とそれによって放射 される騒音との関係について調へる実験である。この実験に おいて, 加振源である燃焼衝撃力のパワーとそれに伴う放射 騒音のパワーとの間には線形関係が成り立つことが知られて いる(1). しかし騒音の発生過程における時間特性を考えた場 合, 図 2(a)に示すように，燃焼衝撃力と放射騒音のピークに 時間遅劢あることが分かる。これは図 2(b)に示すように振 動の減衰効果の影響によるものと考えられ，シリンダ内で発 生した燃狫衝撃が様々な経路を通って複雑に影響し合い，機
関外壁面で騒音として放射されるためであると考えられる。 そこで図 3 に示すような振動の減衰を考慮した騒音の発生モ デルを定義した.ここで $\mathrm{G}_{\mathrm{v}}$ は加振力から振動におけるエネ ルギーの変換係数, $\mathrm{G}_{\mathrm{s}}$ は振動から騒音におけるエネルギー の変換係数を表し, 振動の減衰係数を D で表す.これより $\mathrm{G}_{\mathrm{v}} \mathrm{G}_{\mathrm{s}}$ を伝達放射係数 $\mathrm{G}$ と定義すると，放射騒音は次式で表 される.

$$
W_{e n}(t)=G \cdot W_{c i}(t)+D \cdot W_{e n}(t-\Delta t)
$$

伝達放射係数 $\mathrm{G}$ および減衰係数 D を, 各エンジンにおいて 燃焼衝撃力が発生する期間の平均によりそれぞれ算出し，そ の結果を図 3 に示す。この図より, どちらのエンジンにおい ても伝達放射係数は高周波数で大きくなっていることから， 高周波数域で燃狫衝撃音が放射されやすいことが分かる．ま た減衰係数においては高周波数域になるほど小さくなってい るが,これはエンジン構造内を伝播する横波振動速度が周波 数に依存して高周波数域になるほど大きくなるためであり， 高周波数域になるほど燃焼衝撃力と放射騒音のピークの遅れ が小さくなることを表していることが分かる。これより式(1) を用いて燃焼衝撃音の算出を行った.

\begin{tabular}{|c|c|c|}
\hline \multicolumn{2}{c}{ Table.1 } & Test Engine Specification \\
\hline Type & $\begin{array}{c}\text { Vertical water-cooled } \\
\text { 4 cycle diesel engine }\end{array}$ & $\begin{array}{c}\text { Vertical air-cooled } \\
\text { 4cycle gasoline engine }\end{array}$ \\
\hline Number of cylinder & 1 & 1 \\
\hline Total displacement & $3.10 \times 10^{-4} \mathrm{~m}^{3}$ & $3.99 \times 10^{-4} \mathrm{~m}^{3}$ \\
\hline Compression ratio & 21.5 & 8.5 \\
\hline Bore $\times$ stroke & $74.0 \times 72.0 \mathrm{~mm}$ & $87.0 \times 67.2 \mathrm{~mm}$ \\
\hline Maximum power & $5.88 \mathrm{kw} / 3400 \mathrm{rpm}$ & $19.9 \mathrm{kw} / 7000 \mathrm{rpm}$ \\
\hline Fuel & Diesel fuel No.2 & Gasoline \\
\hline
\end{tabular}

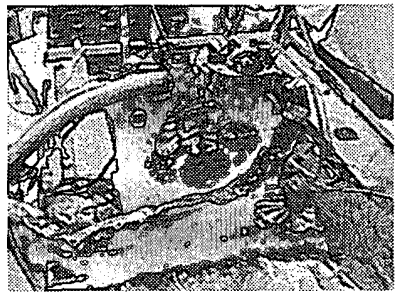

( I) Diesel engine

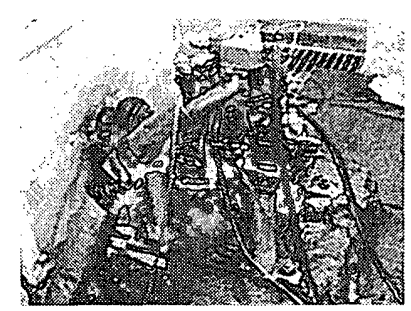

(II) Gasoline engine
Fig.1 Test Engine

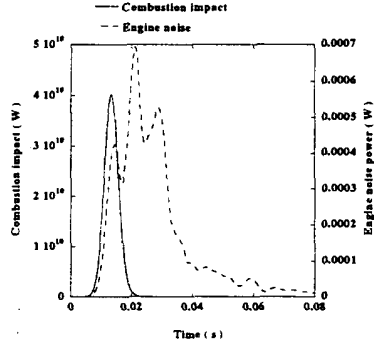

(a) Engine noise

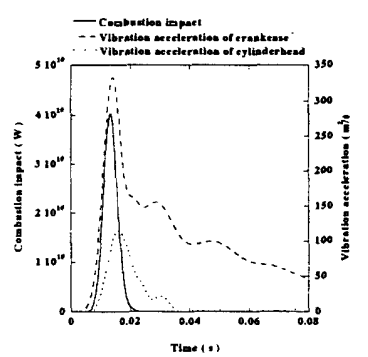

(b) Vibration
Fig.2 Engine noise, combustion impact and engine-wall vibration of single explosion in static gasoline engine $(372 \mathrm{~Hz})$.

日本機械学会講演論文集 No.015-1（'01-3，中国四国支部 第39期総会・講演会） 


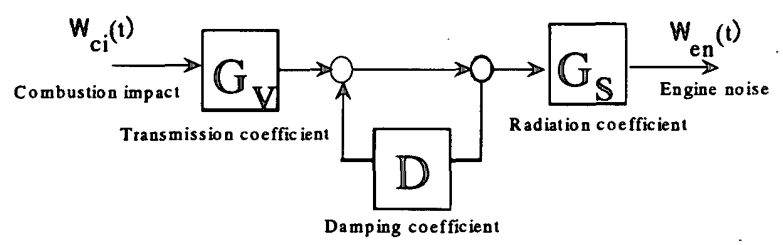

Fig.3 Engine noise generation model

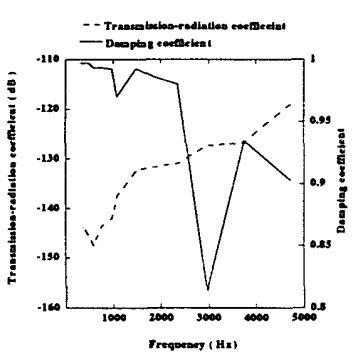

(I) Diesel engine

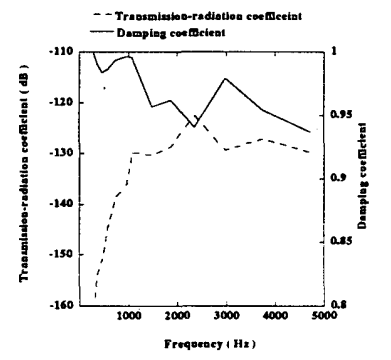

(II) Gasoline engine
Fig.4 transmission-radiation coefficient $G$ and Damping coefficient $\mathrm{D}$ of diesel engine and gasoline engine

4. ティーゼルエンジンとガソリンエンジンの比較

エンジン騒音は，エンジン構造や燃焼状態によって様々に 変化するが,一般にこれらを代表する機関寸法, 負荷, 回転 数などの因子によって表されることが知られている(2)(3). エ ンジン騒音において, シリンダ内圧力に依存して燃焼衝擊音 およで败焼誘起機械騒音が大きくなり，回転数に依存して機 械騒音が大きくなると考えられるので, ティーゼルエンジン およびガソリンエンジンのエンジン騒音のパワーをそれぞれ $\mathrm{W}_{\text {end }}, \mathrm{W}_{\text {eng }}$ とすると, 次式で表される。

$$
\begin{aligned}
& W_{\text {end }}=A_{d} \cdot P_{e}^{\alpha_{d}} \cdot N^{\beta_{d}} \\
& W_{\text {eng }}=A_{g} \cdot P_{e}^{\alpha_{g}} \cdot N^{\beta_{g}}
\end{aligned}
$$

ただし $\mathrm{P}_{\mathrm{e}}$ を正味平均有効圧力， $\mathrm{N}$ を回転数とし， $\mathrm{A} ， \alpha$, 乃は定数を表す.エンジン騒音のパワーは，1 サイクルの時 間平均を求め $295 \mathrm{~Hz}$ から $4724 \mathrm{~Hz}$ までのオーバーオール值 を求めた.ここで同一回転数において，エンジン騒音と正味 平均有効圧の関係を対数で表すと, 図 5(a)となる.この時の 傾きはをれそれ $\alpha_{\mathrm{d}}, \alpha_{\mathrm{g}}$ を表している。同様に同一正味平均 有効圧においてエンジン騷音と回転数を対数で表すと図 $5(\mathrm{~b})$ のようになり，この時の傾きが $\beta_{\mathrm{d}} ， \beta_{\mathrm{g}}$ を表す．これより， それそれのエンジンにおいて $\mathrm{P}_{\mathrm{e}}{ }^{\alpha} \mathrm{N}^{\beta}$ とエンジン騒音のパワ 一の関係について見てみると, 図 6 に示すように線形の関係 が成り立つことが分かり，このときの傾きがそれそれ定数 $A_{d}$, $\mathrm{A}_{\mathrm{g}}$ を表している。 以上のことから式(2)，式(3)は，それそれ 式(4)，式(5)で表される.

$$
\begin{aligned}
& W_{\text {end }}=9.62 \cdot 10^{-16} \cdot P_{e d}^{1.4153} \cdot N^{1.8187} \\
& W_{\text {eng }}=3.25 \cdot 10^{-11} \cdot P_{e_{o}}^{0.0030337} \cdot N^{2.77329}
\end{aligned}
$$

よってティーゼルエンジンとガソリンエンジンを比較すると 指数 $\alpha ， \beta$ の値から，デーゼルエンジンでは燃焼衝擊に依 存する燃焼衝盤音と燃焼誘起機械騒音の影響が大きく, ガソ リンエンジンでは回転数に依存する機械騒音の影響が大きい ことが分かる。

次に各エンジンから発生するエンジン騒音を比較するため にそれそれの図 6 に示すエンジン騒音のパワーで正規化を行 った. 正規化したエンジン騒音および燃焼衝解音の時間周波 数特性を図 7 に示す.これよりディーゼルエンジンにおいて 1 サイクル中に発生するエンジン騒音は, 燃焼上死点付近の 低周波数域で燃焼衝粆音および $1000 \mathrm{~Hz}$ 以上の高周波数域で 燃焼誘起機械騒音の影響が大きく，排気弁開時の $1000 \mathrm{~Hz}$ 付 近で排気吐出し音などの機械騒音の影響が大きいことが分か る.ガソリンエンジンにおいては燃焼衝撃音および然焼誘起 機械騒音の影響はほとんどなく，1000Hz 付近の吸排気弁開
閉時でバルブの着座音や吐出し音などの機械騒音の影響が大 きいことが分かる.

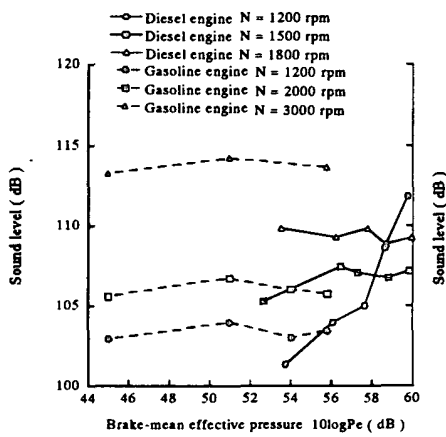

(a)

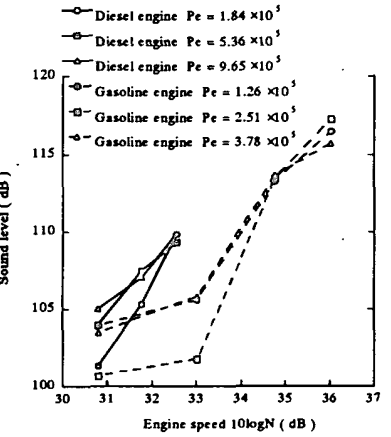

(b)
Fig.5 Relationship between engine noise and brake-mean effective pressure or engine speed

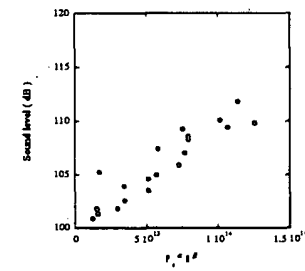

(I) Diesel engine

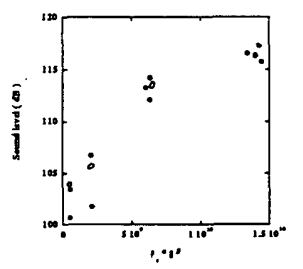

(II) Gasoline engine
Fig.6 Relationship between engine noise and $\mathrm{P}_{\mathrm{e}}^{\alpha} \mathrm{N}^{\beta}$

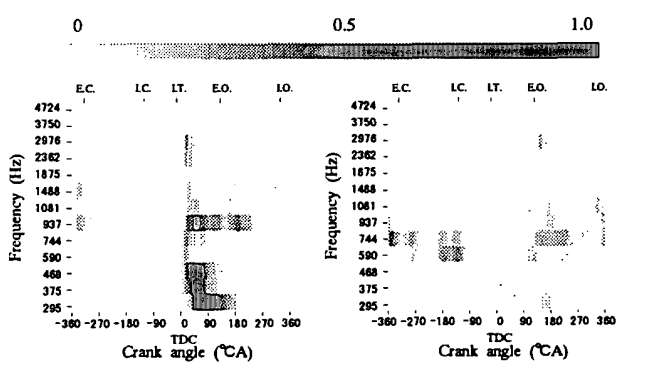

(I) Dieselengine (a) Engine noise

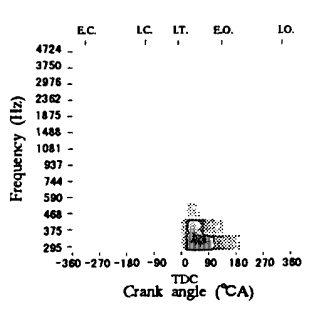

(I) Dieselengine

(b) Combustion noise

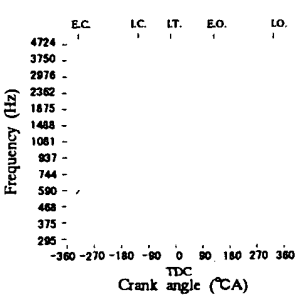

Cank angle (ca)

Fig.7 Time-Frequency characteristics of engine noise and combustion noise

5. 結言

（1）エンジン騒音の発生過程において，振動の減衰特性に よって加振力と放射騷音の間に時間遅れが存在する.

（2）ディーゼルエンジンでは，燃焼上死点付近の低周波数 域で燃焼衝㩓音および $1000 \mathrm{~Hz}$ 以上の高周波数域で燃 焼誘起機械騒音の影響が大きい。

(3) ガソリンエンジンでは，吸排気弁の開閉時における $1000 \mathrm{~Hz}$ 付近の周波数域で機械騒音の影響が大きい。

参考文献

(1) 小嶋ら，自技論 No.37，1988

(2) E.C.Grover, Journal of Sound and Vibration, Vol283,1973

(3) 福田, 自動車技術，27-8，1973 